\title{
In Vitro Antibacterial Activity of Sour Fig (Suurvy) Native to South Africa
}

\author{
Beauty E. Omoruyi, David I. Ighodaro and Francis B. Lewu
}

\begin{abstract}
Sour figs have become a provincial demand in South Africa for the treatment of common infections. The plant has displayed antioxidant activity. The plant leaves were extracted with hexane, acetone, and ethanol using Stuart Sharker, UK. The extracts' antibacterial activity was evaluated by determining the MICs in a range of $7.8-500.0 \mu \mathrm{g} / \mathrm{ml}$ against ten strains using micro-well dilution. Cytotoxicity was evaluated with brine shrimp using the same concentrations. The hexane extract exhibited good activity against $L$. monocytogenes, $S$. pyogenes, $S$. aureus, and S. typhimurium at MIC values of $15.6 \mu \mathrm{g} / \mathrm{ml}$. Acetone extract showed the strongest activity against B. cereus and S. pyogenes at MIC $31.2 \mu \mathrm{g} / \mathrm{ml}$. Ethanol extract displayed MIC activity ranging from 31.2 to $500 \mu \mathrm{g} / \mathrm{ml}$ against all the bacterial strains. The brine shrimps did not survive the various concentrations. The study indicates that the plant possesses potent bioactive activity, but may be toxic to the human body.
\end{abstract}

Key words- Antibacterial, brine shrimps' cytotoxicity, sour fig herbs.

\section{INTRODUCTION}

Coinfection caused by one-cell organisms has seriously complicated the current pandemic mortality rate to increase, especially in critically ill COVID-19 patients [1]. Bacillus cereus, E. faecalis, L. monocytogenes, S. aureus, S. pyogenes and $E$. coli, K. pneumonia, S. typhimurium, S. flexnerii, and $P$. aeruginosa are opportunistic pathogens that are associated with food and waterborne infections [2]. When ingested, they can intracellularly invade healthy humans and animals' intestinal tracts, showing early symptoms of fever, nausea, vomiting, nose bleeding, shortness of breath, seizures, anemia, skin and eye infections [3]. Nevertheless, they can become life-threatening diseases in compromised individuals, causing complicated infections such as- bacteraemia, nosocomial bloodstream infection (BSIs), pneumonia, central nervous system (CNS) infection, urinary tract infection, postsurgical wound infection, endocarditis, brain abscesses, meningitis, sepsis, listeriosis, encephalitis, diarrhoea, dehydration in children, excessive

Manuscript received July 23, 2020. This work was supported by grant (2014SA02231) from National Research Foundation of South Africa.

Beauty E. Omoruyi is with the Applied Microbial and Health Biotechnology Institute, Cape Peninsula University of Technology, Bellville, 7535, SA.

David I. Ighodaro is with the Department of Agriculture, Faculty of Applied Sciences, Cape Peninsula University of Technology, Wellington Campus, Private Bag X8, Wellington, 7654, SA.

Francis B. Lewu is the Department of Agriculture, Faculty of Applied Sciences, Cape Peninsula University of Technology, Wellington Campus, Private Bag X8, Wellington, 7654, SA. bleeding and renal failure in elderly, [4]. Sour fig (suurvy) is a member of the Aizoaceae family, indigenous to South Africa. The traditional healers locally use the roots and leaves of the herb decoction in South Africa to treat and manage ulcers, diarrhoea, high blood pressure, intestinal worms, skin infection, and stomach cramps, sore throats, influenza, and mouth infection [5]. Brine shrimp (Artemia nauplii or sea monkeys) lethality assay is generally used to determine the toxicity effect of bioactive chemicals, including plant extract, fungal toxins, heavy metals, cyanobacteria toxins, pesticides, dental material, and nanostructures [6]. The present study aims to determine the antibacterial and cytotoxic activity of Sour fig to justify its usage.

\section{MATERIALS AND METHODS}

\section{A. Bacterial Strains and Chemicals}

The bacterial strains were selected based on their association with common infections mentioned above. Five strains of Gram-positive bacteria: B. cereus (ATCC 10702), E. faecalis (ATCC 29212), L. monocytogenes (ATCC 12022), S. pyogenes (ATCC 7918), S. aureus (ATCC 6538) and five Gram-negative bacteria: E. coli (ATCC 8739), K. pneumonia (ATCC 4354), S. typhimurium (ATCC 13311), S. flexnerii $(K Z N)$ and $P$. aeroginosa (ATCC 19582) were obtained from the Applied and Environmental Microbiology Research Group (AEMREG), University of Fort Hare, Alice, South Africa. Ciprofloxacin (Cat no: 85721-33-10), $p$-iodonitrotetrazolium violet ( $p$-INT) (Cat no: 146-68-9) and dimethylsulfoxide (DMSO) (Cat no: 67-68-5) were purchased from Sigma-Aldrich (St Lousi, Missouri).

\section{B. Collection of Plant Material}

Samples of sour fig leaves were collected in March - 2014 at 8:30 am in the morning in plastic bags at Nkokonbe Municipality, Eastern Cape Province. The plant was identified by Professor DS Grierson of the Department of Botany, University of Fort Hare, South Africa, in line with the South African National Biodiversity Institute (http://pza.sanbi.org/sour-fig). A voucher sample (012014) was deposited in Giffen's herbarium of the Department of Botany, University of Fort Hare.

\section{Preparation of Plant Extract}

Leaves were softly washed with distilled water, chopped, air-dried at room temperature for approximately five days, and ground into a powder using a Romer Series II Grinding mill (Romer Labs, Newark, Delaware, USA). One hundred and fifty grams (150 g) of leaf powder were sequentially extracted on an 
orbital shaker (Stuart Scientific Orbital Sharker 20.2, SOSI, Essex, UK) with 2 liters of hexane, acetone and ethanol respectively, according to their increasing polarity for $12 \mathrm{~h}$. The extracts were filtered through Whatman No 4 filter paper (Merck, Darmstadt, Germany), and the filtrate re-filtered with Whatman No 1 filter paper $(150 \mathrm{~mm} \varnothing \times 100$ circles, \#1001150) fitted in a Buchner funnel. Filtrates were evaporated to dryness using Heilolph Rotavapor (Germany). The final yield of each extract was recorded and stored desiccated at $4^{\circ} \mathrm{C}$ before use. Each extract was dissolved in DMSO and then in Mueller Hinton broth to reach a final concentration of $500.0 \mu \mathrm{g} / \mathrm{ml}$. Two-fold serial dilutions were made in a concentration range from 7.8 to $500.0 \mu \mathrm{g} / \mathrm{ml}$ in sterile test tubes containing Mueller Hinton broth and used to determine the antimicrobial inhibition activity and the cytotoxic brine shrimp lethality bioassay.

\section{Preparation of Bacterial Inoculums}

The inoculums of the test bacterial strains were prepared using the colony suspension method [7]. Colonies picked from 24 hold cultures grown on nutrient agar were used to make suspensions of the test organisms in saline solution to an optical density of approximately 0.1 at $600 \mathrm{~nm}$. The suspension was then diluted $1: 100 \mathrm{v} / \mathrm{v}$ by transferring $0.1 \mathrm{ml}$ of the bacteria suspension to $9.9 \mathrm{ml}$ of sterile Mueller Hinton broth. The cell turbidity was assessed spectroscopically in comparison to that of the $0.5 \mathrm{McF}$ arland standards (approximately $1.5 \times 108$ $\mathrm{cfu} / \mathrm{ml}$ ) before being used for antibacterial assays [7].

\section{E. Antimicrobial Activity Assay}

Antibacterial assay was determined using a micro-well dilution method [8]. Each extract was dissolved in DMSO and then in Mueller Hinton broth to reach a final concentration of $500.0 \mu \mathrm{g} / \mathrm{ml}$. Two-fold serial dilutions were made in a concentration range from 7.8 to $500.0 \mu \mathrm{g} / \mathrm{ml}$ in sterile test tubes containing Mueller Hinton broth. The 96-well plates were prepared by dispensing into each well $95 \mu \mathrm{l}$ of Mueller Hinton broth, $5 \mu \mathrm{l}$ of the bacteria inoculum, and a $100 \mu \mathrm{l}$ from each serially diluted extracts into respective wells. Another well containing $195 \mu \mathrm{l}$ of Mueller Hinton broth without compound and $5 \mu \mathrm{l}$ of the inoculum on each strip was used as a negative control. The final volume in each well was $200 \mu$ l. Antibiotic ciprofloxacin was tested using the same concentration. Each well was mixed on a plate shaker at $300 \mathrm{rpm}$ for $20 \mathrm{~s}$ prior to incubation at $37^{\circ} \mathrm{C}$ for 24 hours. Each experiment was tested in triplicate. As an indicator of microorganism growth, $40 \mu \mathrm{l}$ of $p$-iodonitrotetrazolium violet ( $p$-INT $-0.2 \mathrm{mg} / \mathrm{ml}$ dissolved in water) was added to each well and incubated at $37{ }^{\circ} \mathrm{C}$ for $30 \mathrm{~min}$ [9]. The microbial growth was inhibited, the solution in the well remained clear after incubation with INT and was taken as its minimum inhibitory concentration $\left(\mathrm{MIC}_{\mathrm{INT}}\right)$ at which no red color occurred. Plating $5 \mu \mathrm{l}$ samples confirmed this from clear wells on Mueller Hinton agar medium. The determinations of MIC values were done in triplicate.

\section{F. Cytotoxicity Test (Brine Shrimp Lethality Bioassay)}

The toxicity of each extract was screened on larvae (nauplii) of Artemia salina (brine shrimp) as described by Lawal et al. [10]. To ensure the mortality effect of the extracts, the control sample containing only nauplii was used as control.
The assay system was conducted by preparing 5 Petri-dishes for each extract in 3 replicates, each containing $20 \mathrm{ml}$ of the filtered seawater from Orient Beach, East London, SA. The second set of petri dishes containing ciprofloxacin dissolved in seawater: $(30 \mu \mathrm{l} \mathrm{ml})$ served as a positive control, while a Petri dish containing only sea water served as the blank control. The setup was allowed to stand for about 30 minutes to allow the solvent to evaporate.

\section{G. Hatching of Artemia Salina Shrimps}

Brine shrimp hatching assay was evaluated by assessing the hatching success of Artemia salina cysts in different concentrations of the plant extracts and positive control [10]. Artemia salina cysts were stocked at a density of 10 individuals per Petri-dish, containing $20 \mathrm{ml}$ of the incubation medium at varying concentrations. The Petri-dishes were partly covered and incubated at $28^{\circ} \mathrm{C}$. The number of free nauplii in each Petridish was counted after every 12 hours, and the setup was allowed to remain for 48 hours under constant oxygen incubator. The percentage of hatchability was assessed by comparing the number of hatched nauplii with the total number of cysts stocked [10]. The number of dead and live nauplii in each well was counted using BX46 dissecting microscopy (Olympic, Life Science Solution, SA). If deaths occurred in controls, the percent death values were evaluated using Abbott's formula:

$(\mathrm{Ca}-\mathrm{Ta}) / \mathrm{Ca} \times 100$, where; $\mathrm{Ca}=$ no of live control nauplii after treatment; $\mathrm{Ta}=$ no of live test nauplii after treatment; $\mathrm{Ca}=$ no of live control nauplii after treatment.

\section{H. Statistical Analysis}

The NCSS 2019 software was used for statistical analysis [11]. Data were subjected to natural $\log (\ln )$ transformation of all variables and analyzed within a generalized linear model ANOVA.

\section{RESULT AND DISCUSSION}

\section{A. In vitro Antimicrobial Activity}

To justify plant source for the treatment and management of illnesses described above by the traditional healers, extracts from $S$. fig leaves were screened in vitro by a broth micro-dilution method against ten pathogenic bacteria. According to the results, hexane extract was active against all the pathogenic bacteria, except for Klebsiella pneumonia, Shigellia flexnerii, and Pseudomonas aeroginosa which had little or no effect at the highest MIC concentration of $500 \mu \mathrm{g} / \mathrm{ml}$ (Table 1). The strongest antibacterial inhibitory activity was seen against Listeria monocytogenes, Streptococcus pyogenes, Staphylococcus aureus, and Salmonella typhimurium with MIC values of $15.6 \mu \mathrm{g} / \mathrm{ml}$ followed by Enterococcus faecalis and Bacillus cereus MIC $31.2 \mu \mathrm{g} / \mathrm{ml}$ and $250.0 \mu \mathrm{g} / \mathrm{ml}$ respectively. Escherichia coli demonstrated weak minimum inhibitory activity at the highest concentration of $500.0 \mu \mathrm{g} / \mathrm{ml}$. Acetone extract suppressed the growth of Gram-positive Bacillus cereus and Streptococcus pyogenes at MIC value of $31.2 \mu \mathrm{g} / \mathrm{ml}$, followed by Staphylococcus aureus, and Shigellia flexnerii which had their MIC at $62.5 \mu \mathrm{g} / \mathrm{ml}$. Weak MIC inhibitory activity of acetone extract at the highest concentration of 500 
$\mu \mathrm{g} / \mathrm{ml}$ was observed for Enterococcus faecalis, Listeria monocytogenes, Salmonella typhimurium and Pseudomonas aeruginosa. Escherichia coli and Klebsiella pneumonia. The ethanol extract displayed MIC activity ranging from $31.2 \mu \mathrm{g} / \mathrm{ml}$ to $500 \mu \mathrm{g} / \mathrm{ml}$ against all the bacteria treated. Reduction of growth inhibition of $31.2 \mu \mathrm{g} / \mathrm{ml}$ MIC was observed for Enterococcus faecalis, followed by Bacillus cereus at 62.5 $\mu \mathrm{g} / \mathrm{ml}$, Listeria monocytogenes at $62.5 \mu \mathrm{g} / \mathrm{ml}$, and Streptococcus pyogenes at $125.0 \mu \mathrm{g} / \mathrm{ml}$. Pseudomonas aeruginosa known to have a high resistant barrier to antibiotics [12], was suppressed by ethanol at MIC value of $125 \mu \mathrm{g} / \mathrm{ml}$, comparable to Ciprofloxacin MIC at $125 \mu \mathrm{g} / \mathrm{ml}$. Escherichia coli, which also has a bad record of multidrug resistance [13], [14], was inhibited by ethanol at MIC of $250 \mu \mathrm{g} / \mathrm{ml}$. The antibiotic ciprofloxacin showed potent inhibitory action against all bacteria tested. At the lowest MIC of $7.8 \mu \mathrm{g} / \mathrm{ml}$, ciprofloxacin was observed to reduce the growth of Bacillus cereus, and Listeria monocytogenes, followed by Staphylococcus aureus, Escherichia coli, and Salmonella typhimurium at MIC value of $15.6 \mu \mathrm{g} / \mathrm{ml}$. The MIC activity of the compound on Klebsiella pneumonia was $31.2 \mu \mathrm{g} / \mathrm{ml}$, Enterococcus faecalis at $62.5 \mu \mathrm{g} / \mathrm{ml}$ and Pseudomonas aeroginosa at $125.0 \mu \mathrm{g} / \mathrm{ml}$.

TABLE I: ANTIMICROBIAL ACTIVITIES OF HEXANE, ACETONE AND ETHANOL EXTRACTS

\begin{tabular}{|c|c|c|c|c|c|}
\hline \multirow[t]{2}{*}{ Microorganisms } & \multicolumn{2}{|c|}{ Gram+/- } & \multicolumn{2}{|c|}{ MIC $^{I N T}$ values $(\mu \mathrm{g} / \mathrm{ml})$} & \multirow[t]{2}{*}{ Ciprofloxacin } \\
\hline & & Hexane & Acetone & Ethanol & \\
\hline Bacillus cereus & $\mathrm{G}+$ & 250.0 & 31.2 & 62.5 & 7.8 \\
\hline $\begin{array}{l}\text { Enterococcus } \\
\text { faecalis }\end{array}$ & G+ & 31.2 & 500.0 & 31.2 & 62.5 \\
\hline $\begin{array}{l}\text { Listeria } \\
\text { monocytogenes }\end{array}$ & G+ & 15.6 & 500.0 & 62.5 & 7.8 \\
\hline $\begin{array}{l}\text { Streptococcus } \\
\text { pyogenes }\end{array}$ & $\mathrm{G}+$ & 15.6 & 31.2 & 125.0 & 7.8 \\
\hline $\begin{array}{l}\text { Staphylococcus } \\
\text { aureus }\end{array}$ & $\mathrm{G}+$ & 15.6 & 62.5 & 250.0 & 15.6 \\
\hline $\begin{array}{l}\text { Escherichia } \\
\text { coli }\end{array}$ & G- & 500.0 & $>500.0$ & 250.0 & 15.6 \\
\hline $\begin{array}{l}\text { Klebsiella } \\
\text { pneumonia }\end{array}$ & G- & $>500.0$ & $>500.0$ & 500.0 & 31.2 \\
\hline $\begin{array}{l}\text { Salmonella } \\
\text { typhimurium }\end{array}$ & G- & 15.6 & 500.0 & 500.0 & 15.6 \\
\hline $\begin{array}{l}\text { Shigellia } \\
\text { flexnerii }\end{array}$ & G- & $>500.0$ & 62.5 & 500.0 & 7.8 \\
\hline $\begin{array}{l}\text { Pseudomonas } \\
\text { aeruginosa }\end{array}$ & G- & $>500.0$ & 500.0 & 125.0 & 125.0 \\
\hline
\end{tabular}

The degree of toxicity of the plant against tested on animals (brine shrimp) was found to be directly proportional to the concentration of the extracts. At $24 \mathrm{hrs}$, maximum mortalities $(100 \%)$ took place from the concentration of 31.2 $\mu \mathrm{g} / \mathrm{ml}$ to $500 \mu \mathrm{g} / \mathrm{ml}$ in hexane extract (Table 2). Moderate mortalities of $12.5 \%$ and $37.5 \%$ were observed at the lowest concentrations of $7.8 \mu \mathrm{g} / \mathrm{ml}$ and $15.6 \mu \mathrm{g} / \mathrm{ml}$, respectively. With acetone extract, maximum $100 \%$ death was observed from 15.6 $\mu \mathrm{g} / \mathrm{ml}$ to $500 \mu \mathrm{g} / \mathrm{ml}$. Only $40 \%$ survived at the least concentration of $7.8 \mu \mathrm{g} / \mathrm{ml}$. Ethanol extract maximum mortalities were observed from $62.5 \mu \mathrm{g} / \mathrm{ml}$ to $500 \mu \mathrm{g} / \mathrm{ml}$. Least mortality rates of $12.5 \%, 20 \%$ and $40 \%$ were seen at the concentrations of $7.8 \mu \mathrm{g} / \mathrm{ml}, 15.6 \mu \mathrm{g} / \mathrm{ml}$ and $31.2 \mu \mathrm{g} / \mathrm{ml}$ respectively.

\begin{tabular}{|c|c|c|c|c|c|c|c|}
\hline TAB & $\begin{array}{l}\text { II: PER } \\
\text { AGAI }\end{array}$ & $\begin{array}{l}\text { ENTAG } \\
\text { T ARTI }\end{array}$ & IORTA & $\begin{array}{l}\text { TY OF } \\
\text { [E (BR] }\end{array}$ & $\begin{array}{l}\text { SOUR F } \\
\text { NE SHR }\end{array}$ & IPS) & \\
\hline & Perc & $\mathrm{ta}$ & ity at & ous & centr & of extra & \\
\hline Extracts & $\begin{array}{l}7.8 \\
\mu \mathrm{g} / \mathrm{ml}\end{array}$ & $\begin{array}{l}15.6 \\
\mu \mathrm{g} / \mathrm{ml}\end{array}$ & $\begin{array}{l}31.2 \\
\mu \mathrm{g} / \mathrm{ml}\end{array}$ & $\begin{array}{l}62.5 \\
\mu \mathrm{g} / \mathrm{ml}\end{array}$ & $\begin{array}{l}125 \\
\mu \mathrm{g} / \mathrm{ml}\end{array}$ & $\begin{array}{l}250 \\
\mu \mathrm{g} / \mathrm{ml}\end{array}$ & $\begin{array}{l}500 \\
\mu \mathrm{g} / \mathrm{m}\end{array}$ \\
\hline Hexane & $12.5 \%$ & $37.5 \%$ & $100 \%$ & $100 \%$ & $100 \%$ & $100 \%$ & $100 \%$ \\
\hline Acetone & $40 \%$ & $100 \%$ & $100 \%$ & $100 \%$ & $100 \%$ & $100 \%$ & $100 \%$ \\
\hline Ethanol & $12.5 \%$ & $20 \%$ & $40 \%$ & $100 \%$ & $100 \%$ & $100 \%$ & $100 \%$ \\
\hline
\end{tabular}

\section{CONCLUSION}

In summary, the results confirm the plant possesses potent bioactive activity against both Gram-positive and Gram-negative bacteria: but was found toxic to brine shrimps on exposure for $24 \mathrm{hr}$ to $48 \mathrm{hr}$ in a dose- dependent manner. Caution should be taken as the plant may be toxic to the human body.

\section{ABBREVIATIONS}

B.S.L.T: Brine shrimp lethality assays., C.N.S: Central nervous system., A.T.C.C: America type culture collection., A.E.M.R.E.G: Applied and environmental microbiology research group., $p$-INT: $p$-iodonitrotetrazolium violet., D.M.S.O: Dimethylsulfoxide.

\section{REFERENCES}

[1] P. Zhou, Z. Liu, Y. Chen, Y. Xiao, X. Huang, and X. Fan, "Bacterial and fungal infections in COVID-19 patients: A matter of concern," Infect. Cont. and Hospital Epidemiol., pp. 1-2, April 2020. https://doi.org/10.1017/ice.2020.156

[2] T. Saha, P. Kumar, N. Sepay, D. Ganguly, K. Tiwari, K. Mukhopadhyay, and S. Das, "Multi-targeting antibacterial activity of a synthesized Mn2+ complex of curcumin on Gram-positive and Gram-negative bacterial strains," ACS Omega., vol. 5, no. 27, pp. 16342-16357, August 2020. https://doi.org/10.1021/acsomega.9b04079

[3] C. R. Maclntyre, A. A. Chughtai, M. Barnes, M. Ridda, H. Seale, R, Toms, and A. Heywood "The role of pneumonia and secondary bacterial infection in fatal and serious outcomes of pandemic influenza a(H1N1) pdm09," BMC Infect. Dis., vol. 18, pp. 637, December2018. https://doi.org/10.1186/s12879-018-3548-0

[4] W. Wei, L. Li, Z. Liu, Y. Deng, D. Chen, P. Gu, G. Wang, and X. Fan, "Distinct antibacterial activity of a vertically aligned graphene coating against Gram-positive and Gram-negative bacteria," J. Materials Chem. B., vol. 8, pp. 5965-6160, June 2020 . https://doi.org/10.1039/D0TB00417K

[5] B. E. Omoruyi, G. Bradley, and A. J. Afolayan, "Ethnomedicinal survey of medicinal plants used for the management of HIV/AIDS infection among local communities of Nkonkobe Municipality Eastern Cape South Africa," J. Med. Plant Res., vol. 6, no.19, pp. 3603-3608, May 2012. https://doi.org/10.5897/JMPR12.541

[6] S. S. Quazi, F.A. Chowdhury, and M. Misbahuddin, "Brine shrimp lethality assay," Bangladesh J. Pharmacol., vol. 12, pp. 186-189, June 2017. https://doi.org/10.3329/bjp.v12i2.32796

[7] M. Hombach, F. P. Maurer, T. Pfiffner, E. C. Bottger, and R. Furrer, "Standardization of operator-dependent variables affecting precision and accuracy of the disk diffusion method for antibiotic susceptibility testing," J. Clin. Microbiol., vol. 53, no. 12, pp. 3864-3869, December 2015. https://doi.org/10.1128/JCM.02351-15

[8] A. A. Mostafa, A. A. Al-Askar, K. S. Almaary, T. M. Dawoud, E. N. Sholkamy, and M. M. Bakri, "Antimicrobial activity of some plant 
extracts against bacterial strains causing food poisoning diseases," Saudi J. Biol. Sci., vol. 25, no. 2, pp. 361-366, February 2018. https://doi.org/10.1016/j.sjbs.2017.02.004

[9] M. M. Meelah, L. K. Mdee, and J. N. Eloff, "Tecoma stans (Bignoniaceae), leaf extracts, fractions and isolated compound have promising activity against fungal phytopathogens," Suid-Afrikaanse Tydskrif vir Natuurwetenskap en Tegnologie., vol. 36, no. 1, pp. a1489, December 2017. https://doi.org/10.4102/satnt.v36i1.1489

[10] O. A. Lawal, I. A. Ogunwande, M. S. Owolabi, A. R. Opoku, and A. O. Oyedeji, "Chemical composition, antibacterial activity, and brine shrimp lethality test of essential oil from the leaves of Eugenia natalitia," Chem. Nat. Compd., vol. 52, pp. 731-733, June 2016. https://doi.org/10.1007/s10600-016-1758-5

[11] NCSS 2019 Statistical Software, "NCSS, LLC. Kaysville, Utah, USA," ncss.com/software/ncss, 2019.

[12] S. Chevalier, E. Bouffartigues, J. Bodilis, M. Olivier, O. Lesouhaitier, and M. G. J. Feuilloley, "Structure, function and regulation of Pseudomonas aeruginosa porins," FEMS Microbiol. Rev., vol. 41, no. 5, pp. 698-722, September 2017. https://doi.org/10.1093/femsre/fux020

[13] S. T. Odonkor, and K. K. Addo, "Prevalence of multidrug-resistant Escherichia coli isolated from drinking water sources," Int. J. Microbiol., vol. 2018 7204013, August 2018. https://doi.org/10.1155/2018/7204013

[14] C. L. Cazer, M. A. Al-Mamum, K. Kaniyamattam, W. J. Love, J. G. Booth, C. Lanzas, and Y. T. Grohn, "Shared multidrug resistance patterns in chicken-associated Escherichia coli identified by association rule mining," Front. Microbiol., vol. 10, pp. 687, April 2019. https://doi.org/10.3389/fmicb.2019.00687

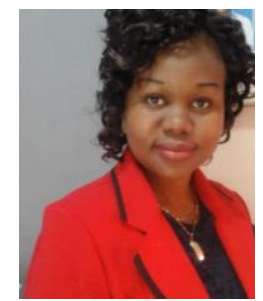

Dr Omoruyi E. Beauty is a member of the South African Society for Biochemistry and Microbiology Biology (SASBMB), SA. She is a PhD degree holder in Biochemistry from the University of Fort Hare, 2014. Research discipline(s): Biochemistry, Biomedicine \& Microbial Biotechnology. For the past 9 years, her research had focused on understanding the pathophysiology of chronic diseases in South Africa; finding novel bio-controls that can be utilized for disease prevention. She is currently employed by the Applied Microbial and Health Biotechnology Institute, Cape Peninsula University of Technology, Cape Town as a POSTDOCTORAL RESEARCH FELLOW. Her research outputs can be found in the https://orcid.org/0000-0001-9178-7539. 